\title{
Intensity of musculoskeletal pain and (in) ability to work in nursing ${ }^{1}$
}

\author{
Tânia Solange Bosi de Souza Magnago² \\ Ana Cláudia Soares de Lima ${ }^{3}$ \\ Andrea Prochnow ${ }^{4}$ \\ Marinez Diniz da Silva Ceron ${ }^{4}$ \\ Juliana Petri Tavares ${ }^{5}$ \\ Janete de Souza Urbanetto ${ }^{6}$
}

\begin{abstract}
Objective: the aim was to evaluate the association between the intensity of musculoskeletal pain and reduction in work ability among nursing workers. Method: a cross-sectional study, involving 592 nursing staff in a public university hospital in Rio Grande do Sul, Brazil. The Brazilian version of the Finnish questionnaire for calculating Work Ability Index was used, whose score varies from 7 to 49 points. The score was dichotomized as reduced work ability (7 to 36 points) and good/excellent ability (37 to 49 points). The intensity of musculoskeletal pain over the previous week was evaluated, using a numerical pain scale. Result: $43.3 \%$ of the participants had reduced work ability and $48.8 \%$ reported strong to unbearable pain. Even after adjusting for potentially confounding factors (function and length of service in the function), the workers who mentioned strong to unbearable pain were four times more likely to be classified in the group with reduced work ability. Conclusion: A positive association was determined between intensity of musculoskeletal pain and reduction in work ability. It is necessary to adopt intervention measures in the organizational structure, so as to promote/restore work ability.

Descriptors: Nursing; Occupational Health; Work Capacity Evaluation; Cumulative Trauma Disorders; Pain.
\end{abstract}

\footnotetext{
${ }^{1}$ Paper extrated from Project Recém Doutor and from Final Course Assignment "Condições de trabalho, dor musculoesquelética e índice de capacidade para o trabalho da equipe de enfermagem". Supported by Universidade Federal de Santa Maria, process \# 23081.006225/2009-69 and Fundação de Amparo à Pesquisa do Rio Grande do Sul, process \# 0903826.

2 PhD, Professor, Universidade Federal de Santa Maria, Brazil.

3 Master's Student, Universidade Federal do Rio Grande do Sul, Brazil.

${ }^{4}$ Master's Student, Universidade Federal de Santa Maria, Brazil.

${ }^{5}$ Doctoral Student, Universidade Federal do Rio Grande do Sul, Brazil.

${ }^{6}$ PhD, Adjunct Professor, Pontifícia Universidade Católica do Rio Grande do Sul, Brazil.
}

Corresponding Author:

Tânia Solange Bosi de Souza Magnago

Universidade Federal de Santa Maria

Av. Roraima, 1000 , prédio 26

Camobi

CEP: 97105-900, Santa Maria, Brasil

E-mail: tmagnago@terra.com.br 


\section{Intensidade da dor musculoesquelética e a (in)capacidade para o trabalho na enfermagem}

Objetivo: objetivou-se avaliar a associação entre intensidade da dor musculoesquelética e redução da capacidade para o trabalho em trabalhadores de enfermagem. Método: trata-se de estudo transversal, envolvendo 592 trabalhadores de enfermagem de um hospital universitário público do Rio Grande do Sul, Brasil. Utilizou-se a versão brasileira do questionário finlandês, para o cálculo do Índice de Capacidade para o Trabalho, cujo escore dos pontos varia de 7 a 49. A pontuação foi dicotomizada como reduzida capacidade para o trabalho ( 7 a 36 pontos) e boa/ótima capacidade (37 a 49 pontos). Avaliou-se a intensidade de dor musculoesquelética na última semana, utilizando-se escala numérica de dor. Resultado: dos participantes, 43,3\% apresentaram reduzida capacidade para o trabalho e 48,8\% relataram dor de intensidade forte a insuportável. Mesmo após ajustes pelos potenciais fatores de confundimento (função e tempo na função), os trabalhadores que referiram dor forte a insuportável tiveram quatro vezes mais chances de serem classificados no grupo com reduzida capacidade para o trabalho. Conclusão: constata-se associação positiva entre intensidade da dor musculoesquelética e redução da capacidade para o trabalho. Faz-se necessária a adoção de medidas interventivas na estrutura organizacional, a fim de promover/restaurar a capacidade para o trabalho.

Descritores: Enfermagem; Saúde do Trabalhador; Avaliação da Capacidade de Trabalho; Transtornos Traumáticos Cumulativos; Dor.

\section{Intensidad del dolor musculo-esquelético y la (in)capacidad para el trabajo en la enfermería}

Objetivo: se objetivó evaluar la asociación entre intensidad del dolor musculo-esquelético y reducción de la capacidad para el trabajo en trabajadores de enfermería. Método: Estudio transversal, envolviendo 592 trabajadores de enfermería de un hospital universitario público de Rio Grande do Sul, Brasil. Se utilizó la versión brasileña del cuestionario Finlandés para el cálculo del Índice de Capacidad para el Trabajo, cuyo score de los puntos varia de 7 a 49. La puntuación fue dicotómica como reducida capacidad para el trabajo ( 7 a 36 puntos) y buena/ óptima capacidad (37 a 49 puntos). Se evaluó la intensidad de dolor musculo-esquelético en la última semana, utilizándose escala numérica de dolor. Resultado: De los participantes, 43,3\% presentaron reducida capacidad para el trabajo y $48,8 \%$ relataron dolor de intensidad fuerte a insoportable. Mismo después de ajustes por los potenciales factores de confundimiento (función y tiempo en la función), los trabajadores que refirieron dolor fuerte a insoportable tuvieron cuatro veces más chances de ser clasificados en el grupo con reducida capacidad para el trabajo. Conclusión: se constata asociación positiva entre intensidad del dolor musculoesquelético y reducción de la capacidad para el trabajo. Se hace necesario la adopción de medidas de intervención en la estructura organizacional, a fin de promover/restaurar la capacidad para el trabajo.

Descriptores: Enfermería; Salud Laboral; Evaluación de Capacidad de Trabajo; Trastornos de Traumas Acumulados; Dolor.

\section{Introduction}

Musculoskeletal disorders determine a set of signs and symptoms (pain, discomfort, paresthesia, sensation of heaviness, fatigue, limitation of movement and inability to work) which may be concurrent, which may begin insidiously and develop rapidly in the absence of changes in the work conditions ${ }^{(1)}$. These constitute an important public health problem in various industrialized countries and affect workers from a variety of professions $^{(1)}$, including Nursing ${ }^{(2-6)}$.

Reports from nursing workers who feel musculoskeletal pain (MSP) are present in the context of the University Hospital of Santa Maria (UHSM), Rio Grande do Sul, Brazil. In 2006 a study(5) was undertaken in this institution, evaluating the psycho-social aspects 
of the nursing work (psychological demands and control over the work) ${ }^{(7)}$ and the relationship with the occurrence of musculoskeletal disorders. It evidenced high percentages of reports of MSP both over the previous year and in the seven days prior to the survey.

When it was seen that high psychological demands and low control - configured as high strain at work ${ }^{(7)}$ were significantly harmful to the health of this institution's nursing workers, the motivation arose to investigate the elements with potential for triggering alterations in work ability, including MSP. It was hypothesized that the intensity of the MSP could be directly implicated in reducing work ability among nursing professionals.

In relation to studies carried out with health sector workers, research in Brazil points to the early loss of work ability ${ }^{(8-13)}$. This loss was related to night work ${ }^{(11)}$, to individual characteristics and to work characteristics ${ }^{(8-12)}$ and to work-related stress ${ }^{(13)}$. Evidence was not found of studies evaluating the relationship between work ability and the intensity of the musculoskeletal pain. This relationship can be evaluated through the Work Ability Index (WAI) $)^{(14)}$, a questionnaire devised by researchers from the Finnish Institute of Occupational Health, which evaluates "how good is the worker at present, in the near future, and how able is he/she to do his/her work with respect to the work demands, health and mental resources"(14). This questionnaire was translated from the original in English to Portuguese by a multidisciplinary group of researchers, was adapted to Brazilian Portuguese and published in Portuguese by the Finnish Institute of Occupational Health in 1997, and by EDUFSCAR in $2005^{(14)}$.

Based on the guiding question "is there an association between the intensity of MSP and reduction in work ability in nursing?", the present work aimed to evaluate the association between the intensity of the MSP and the reduction in work ability in nursing workers in a public university hospital in Rio Grande do Sul, Brazil. In this context, it has as its object of study the Work Ability Index of workers in hospital nursing.

\section{Method}

This is a cross-sectional study, approved by the Research Ethics Committee of the teaching institution to which the authors are linked (CAAE 0070.0.243.000-09), in June 2009. The 592 nursing workers who had passed public contests for the positions and were working in the public University Hospital of Rio Grande do Sul (Brazil) were defined as eligible. The inclusion criteria were that the worker had to have entered the institution by passing the public contest and be exercising his or her work function at the time the study was undertaken. Workers on leave or removed from their duties for any reason during the data collection period were excluded.

Data collection was carried out between September and December 2009, by means of the administration of a questionnaire with closed questions referring to the $\mathrm{WAI}^{(14)}$, with relation to musculoskeletal pain ${ }^{(15)}$, sociodemographic variables, and work variables. Distribution and recovery of the questionnaires was done by student nurses, previously trained by the research's coordinator. Following clarification about the research's objective, the workers who accepted to participate signed the Terms of Free and Informed Consent (TFIC), receiving, filling out and returning the questionnaire during their work shift.

The Brazilian version(14) of a self-administered instrument developed in Finland was used to evaluate the WAI (dependent variable). The score from the points varied from 7 to 49, being divided from 7 to 27 (poor work ability), 28 to 36 (moderate ability), 37 to 43 (good ability) and 44 to 49 (excellent ability) ${ }^{(14)}$. For the comparison with the study's other variables, the WAI score was dichotomized as reduced work ability (7 to 36 points) and good/excellent ability ( 37 to 49 points).

The exposure - intensity of the MSP (independent variable) - was evaluated using a numerical pain scale(15) adapted for evaluating pain of musculoskeletal origin perceived in the preceding week. The score varied from zero to 10 , where zero represented a total absence of pain, and 10 , the most intense pain yet experienced by the individual. For the analyses, the intensity of the pain was categorized as: absent (zero), weak or moderate pain (1 to 6 ) and strong to unbearable pain ( 7 to 10 ).

Other variables evaluated were: a) sociodemographic variables: sex (female or male); age in tertiles (24 to 36 years; 37 to 46 years and 47 to 69 years; race (Caucasian, Afro-Brazilian, mixed race or Asian); schooling (graduate or not) and marital situation (single; married; separated, divorced, widowed), b) work variables: function (nurse; nurse technician or nursing assistant; unit where worker works; length of service in that function and in the unit; shift (day or night); weekly hour load (30h and 36h); second job (yes or no) and weekly hour load in second job (up to $20 \mathrm{~h}$ and over $21 \mathrm{~h}$ ).

The Epi-info $®$ program, version 6.04, was used for insertion of the data, with independent double keying. After verification for errors and inconsistencies, data 
analysis was done using the program PASW Statistics ${ }^{\circledR}$ (Predictive Analytics Software, from SPSS Inc., Chicago - USA), version 18.0 for Windows. Descriptive statistics (measurements of position and dispersion) was used for the analyses of the continuous variables. The categorical variables were evaluated in percentages. In the analyses between the outcome and each of the variables studied, the Chi-square test or Fisher's Exact test were used to verify the statistical significance $(p<0.05)$ at levels of confidence of $95 \%$.

Binary logistical regression was used (by the Enter method) to identify the association adjusted by confounding factors between the WAI and the level of musculoskeletal pain. In these analyses, the co-variables were considered as confounding factors if associated as much with the outcome (WAI) as with the exposure (intensity of musculoskeletal pain) at a confidence level of $75 \%$ ( $p \leq 0.25$ ). The measure of association used was the Odds Ratio (OR) and its respective confidence intervals (CI95\%). In the regression model adopted, an evaluation of multicollinearity was undertaken, using the calculation of the Variance Inflation Factor (VIF). In this, the minimum possible value is equal to 1.0 , and values $>10.0$ may indicate a problem of colinearity. The Hosmer and Lemeshow test was used to establish the best adjusted model (closest to 1.0).

\section{Results}

Of the total population eligible to participate in the study (592), 498 (84\%) responded to the instrument. The losses $(16 \% ; \mathrm{N}=94)$ resulted from refusals to participate.

Characterization of the population: the predominance of women was observed $(87.8 \% ; \mathrm{N}=437)$, aged between 47 and $69(32.7 \% ; \mathrm{N}=163)$, Caucasian (85.3\%; $N=425)$ and married (69.3\%; $N=345)$. In relation to the work profile, the nurse technicians and auxiliary nurses predominated $(73.5 \% ; \mathrm{N}=366)$; they had worked in their current function for an average of
14.3 years $( \pm 8.6)$ and in their current unit for eight years $( \pm 7.1)$ on the night shift $(40 \% ; N=199)$; they worked 36 hours per week $(62.4 \% ; \mathrm{N}=311)$ and the minority $(17.9 \% ; \mathrm{N}=89)$ stated that they also worked elsewhere*. Of these, $90.8 \%$ had one more job, and $9.2 \%$ had two. The weekly hour load in the other job varied from 5 to 44 hours, with an average of 27 hours ( \pm 10.8$)$.

Characterization of the intensity of the MSP(15): when the intensity of the musculoskeletal pain or discomfort was evaluated, $8.6 \%(\mathrm{~N}=43)$ did not mention pain in the seven days prior to the interview; $11.6 \%(\mathrm{~N}=112)$ had had pain of weak intensity, 35.7\% $(\mathrm{N}=188)$ moderate pain, 39\% $(\mathrm{N}=194)$ strong pain and $5.1 \%(\mathrm{~N}=25)$ unbearable pain.

Characterization of the $W A I^{(14)}: 5.7 \%(N=29)$ of the workers were classified as with poor work ability, 37.6\% $(\mathrm{N}=187)$ with moderate ability, $41.4 \%(\mathrm{~N}=206)$ with good ability and $15.3 \%(\mathrm{~N}=76)$ with excellent ability. Following dichotomization of these categories, $43.3 \%(N=216)$ of the workers had poor/moderate work ability (reduced ability) and $56.7 \%(\mathrm{~N}=282)$ good/excellent ability.

Table 1- Distribution of nursing workers in the University Hospital according to the Work Ability Index (WAI), according to the level of musculoskeletal pain. Santa Maria, Rio Grande do Sul, Brazil, Sept/Dec 2009 (N=498)

\begin{tabular}{|c|c|c|c|c|c|}
\hline \multirow{3}{*}{$\begin{array}{l}\text { Intensity of the } \\
\text { musculoskeletal } \\
\text { pain }\end{array}$} & \multicolumn{4}{|c|}{ WAI } & \multirow{3}{*}{$\mathbf{p}^{*}$} \\
\hline & \multicolumn{2}{|c|}{$\begin{array}{c}\text { Poor/moderate } \\
\text { ability }\end{array}$} & \multicolumn{2}{|c|}{$\begin{array}{c}\text { Good/excellent } \\
\text { ability }\end{array}$} & \\
\hline & $\mathbf{N}$ & $\%$ & $\mathbf{N}$ & $\%$ & \\
\hline Absent & 10 & 23.3 & 33 & 76.7 & \multirow{4}{*}{$<0.0001$} \\
\hline Weak to moderate & 75 & 31.8 & 161 & 68.2 & \\
\hline Strong to unbearable & 131 & 59.8 & 88 & 40.2 & \\
\hline Total & 216 & 43.4 & 282 & 56.6 & \\
\hline
\end{tabular}

* Pearson's Chi-squared test.

Table 1 evidences the significant difference between the groups evaluated and a positive linear association, with a dose-response gradient. 
Table 2 - Distribution of nursing workers in the University Hospital according to the intensity of musculoskeletal pain and the Work Ability Index (WAI), according to sociodemographic characteristics. Santa Maria, Rio Grande do Sul, Brazil, Sept/Dec 2009 ( $N=498)$

\begin{tabular}{|c|c|c|c|c|c|c|c|c|}
\hline \multirow{3}{*}{ Sociodemographic variables } & \multicolumn{5}{|c|}{ Intensity of musculoskeletal pain } & \multirow{2}{*}{\multicolumn{3}{|c|}{$\frac{\text { WAI }}{\text { Reduced ability }}$}} \\
\hline & \multicolumn{2}{|c|}{ Weak to moderate } & \multicolumn{2}{|c|}{ Strong to unbearable } & \multirow{2}{*}{$\mathbf{p}^{*}$} & & & \\
\hline & $\mathbf{N}$ & $\%$ & $\mathbf{n}$ & $\%$ & & $\mathbf{n}$ & $\%$ & $\mathbf{p}^{*}$ \\
\hline $\operatorname{Sex}(N=496)$ & & & & & $<0.001$ & & & 0.001 \\
\hline Female & 194 & 44.4 & 207 & 47.4 & & 200 & 45.8 & \\
\hline Age range/in tertile $(\mathrm{N}=480)$ & & & & & 0.062 & & & 0.021 \\
\hline 24 to 36 years & 89 & 57.4 & 56 & 36.1 & & 55 & 35.5 & \\
\hline 37 to 46 years & 68 & 42.0 & 78 & 48.1 & & 69 & 42.6 & \\
\hline 47 to 69 years & 72 & 44.2 & 75 & 46.0 & & 83 & 50.9 & \\
\hline Schooling $(\mathrm{N}=497)$ & & & & & 0.537 & & & 0.108 \\
\hline High school & 85 & 44.3 & 92 & 47.9 & & 84 & 43.7 & \\
\hline Undergraduate & 68 & 47.6 & 64 & 44.8 & & 71 & 49.7 & \\
\hline Post-graduate & 83 & 51.2 & 63 & 38.9 & & 61 & 37.7 & \\
\hline Marital status $(\mathrm{N}=493)$ & & & & & 0.700 & & & 0.898 \\
\hline Married/with partner & 166 & 48.1 & 152 & 44.1 & & 149 & 43.2 & \\
\hline Single/without partner & 69 & 46.6 & 64 & 43.2 & & 63 & 42.6 & \\
\hline Race $(N=492)$ & & & & & 0.266 & & & 0.407 \\
\hline Afro-Brazilian & 07 & 46.7 & 07 & 46.7 & & 06 & 40.0 & \\
\hline Mixed/Asian/Indigenous & 20 & 38.5 & 30 & 57.7 & & 27 & 51.9 & \\
\hline Caucasian & 207 & 48.7 & 179 & 42.1 & & 180 & 42.4 & \\
\hline
\end{tabular}

* Pearson's Chi-Squared test.

Being female showed higher percentages both for level of pain being described as unbearable and for reduction of work ability $(p<0.001)$. Workers aged over 47 had a higher percentage for reduced ability $(p=0.021)$.

Table 3 - Distribution of nursing workers at the University Hospital according to the intensity of the musculoskeletal pain and the Work Ability Index (WAI), according to work characteristics. Santa Maria, Rio Grande do Sul, Brazil, Sept/Dec $2009(N=498)$

\begin{tabular}{|c|c|c|c|c|c|c|c|c|}
\hline \multirow{3}{*}{ Work variables } & \multicolumn{5}{|c|}{ Intensity of musculoskeletal pain } & \multirow{2}{*}{\multicolumn{3}{|c|}{$\frac{\text { WAI }}{\text { Reduced ability }}$}} \\
\hline & \multicolumn{2}{|c|}{ Weak to moderate } & \multicolumn{3}{|c|}{ Strong to unbearable } & & & \\
\hline & $\mathbf{n}$ & $\%$ & $\mathbf{n}$ & $\%$ & $\mathbf{p}^{*}$ & $\mathbf{n}$ & $\%$ & $\mathbf{p}^{*}$ \\
\hline Role & & & & & 0.019 & & & 0.059 \\
\hline Nurse & 77 & 53.5 & 50 & 34.7 & & 53 & 36.8 & \\
\hline Nurse tech/Auxiliary nurse & 159 & 44.9 & 169 & 47.7 & & 163 & 46.0 & \\
\hline Work shift & & & & & 0.108 & & & 0.645 \\
\hline Day & 96 & 45.5 & 102 & 48.3 & & 89 & 42.2 & \\
\hline Night & 140 & 48.8 & 117 & 40.8 & & 127 & 44.3 & \\
\hline Length of service in role $(\mathrm{N}=492)$ & & & & & 0.022 & & & 0.106 \\
\hline Up to 13 years & 135 & 52.9 & 101 & 39.6 & & 101 & 39.6 & \\
\hline$\geq 14$ years & 96 & 40.5 & 118 & 49.8 & & 111 & 46.8 & \\
\hline $\begin{array}{l}\text { Length of time in department } \\
(\mathrm{N}=486)\end{array}$ & & & & & 0.956 & & & 0.606 \\
\hline Up to six years & 123 & 47.3 & 115 & 44.2 & & 109 & 41.9 & \\
\hline$\geq$ seven years & 109 & 48.2 & 97 & 42.9 & & 100 & 44.2 & \\
\hline Weekly hour load (WL) & & & & & 0.349 & & & 0.026 \\
\hline 30 hours/week & 83 & 44.4 & 84 & 44.9 & & 93 & 49.7 & \\
\hline 36 hours/week & 153 & 49.2 & 135 & 43.4 & & 123 & 39.5 & \\
\hline Other job $(\mathrm{N}=89)$ & & & & & 0.669 & & & 0.073 \\
\hline Yes & 46 & 51.7 & 36 & 40.4 & & 31 & 34.8 & \\
\hline
\end{tabular}


Table 3 - (continuation)

\begin{tabular}{|c|c|c|c|c|c|c|c|c|}
\hline \multirow{3}{*}{ Work variables } & \multicolumn{5}{|c|}{ Intensity of musculoskeletal pain } & \multirow{2}{*}{\multicolumn{3}{|c|}{$\frac{\text { WAI }}{\text { Reduced ability }}$}} \\
\hline & \multicolumn{2}{|c|}{ Weak to moderate } & \multicolumn{3}{|c|}{ Strong to unbearable } & & & \\
\hline & $\mathbf{n}$ & $\%$ & n & $\%$ & $\mathbf{p}^{*}$ & $\mathbf{n}$ & $\%$ & $\mathbf{p}^{*}$ \\
\hline WL other job $(\mathrm{N}=82)$ & & & & & 0.835 & & & 0.050 \\
\hline Up to 20 hours & 19 & 48.7 & 16 & 41.0 & & 17 & 43.6 & \\
\hline$>20$ hours ( 21 to $44 \mathrm{~h})$ & 23 & 53.5 & 17 & 39.5 & & 10 & 23.3 & \\
\hline
\end{tabular}

* Pearson's Chi-Squared test

The nurse technicians/auxiliary nurses and those with the longest service in their current function reported pain with strong to unbearable intensity. The workers who work 30 hours per week in the institution surveyed and those who carry out activity with WL of up to 20 hours per week in another job have an association with reduced work ability (Table 3 ).

Table 4 - Unadjusted and adjusted associations between the levels of intensity of musculoskeletal pain and the Work Ability Index (WAI). Santa Maria, Rio Grande do Sul, Brazil, Sept/Dec 2009 (N=498)

\begin{tabular}{|c|c|c|c|c|}
\hline \multirow[b]{2}{*}{ Variables } & \multicolumn{4}{|c|}{ WAI $^{*}$ - Reduced work ability } \\
\hline & OR & (Cl 95\%) & $\begin{array}{c}\text { Variance Inflation } \\
\text { Factor }\end{array}$ & $\begin{array}{c}\text { Hosmer and } \\
\text { Lemeshow test }\end{array}$ \\
\hline Unadjusted association & & & & 1.00 \\
\hline \multicolumn{5}{|l|}{ Musculoskeletal pain } \\
\hline Absent & 1.00 & --- & & \\
\hline Weak to moderate & 1.54 & $(0.72-3.28)$ & & \\
\hline Strong to unbearable & 4.91 & $(2.30-10.48)^{\S}$ & & \\
\hline Adjusted association $1^{\dagger}$ & & & & 0.491 \\
\hline Musculoskeletal pain & & & 1.128 & \\
\hline Absent & 1.00 & ---- & & \\
\hline Weak to moderate & 1.39 & $(0.64-3.02)$ & & \\
\hline Strong to unbearable & 4.22 & $(1.94-9.17)^{\S}$ & & \\
\hline \multicolumn{5}{|l|}{ Sex } \\
\hline Male & 1.00 & ----- & 1.053 & \\
\hline Female & 1.90 & $(0.97-3.72)$ & & \\
\hline \multicolumn{5}{|l|}{ Age } \\
\hline 24 to 36 years & 1.00 & ----- & 1.662 & \\
\hline 37 to 46 years & 1.23 & $(0.71-2.13)$ & & \\
\hline 47 to 69 years & 1.87 & $(1.01-3.46)$ & & \\
\hline Function & & & 1.037 & \\
\hline Nurse & 1.00 & ---- & & \\
\hline Nurse tech/Auxiliary nurse. & 1.37 & $(0.88-2.13)$ & & \\
\hline \multicolumn{5}{|l|}{ Length of time in function } \\
\hline Up to 13 years & 1.00 & ----- & 1.649 & \\
\hline$\geq 14$ years & 0.87 & $(0.52-1.44)$ & & \\
\hline Adjusted association $2^{\ddagger}$ & & & & 0.821 \\
\hline Musculoskeletal pain & & & 1.021 & \\
\hline Absent & 1.00 & ---- & & \\
\hline Weak to moderate & 1.43 & $(0.66-3.09)$ & & \\
\hline Strong to unbearable & 4.60 & $(2.14-9.89)^{\S}$ & & \\
\hline Function & & & 1.017 & \\
\hline Nurse & 1.00 & ----- & & \\
\hline Nurse tech/Auxiliary nurse & 1.28 & $(0.84-1.95)$ & & \\
\hline Length of time in function & & & 1.004 & \\
\hline Up to 13 years & 1.00 & ----- & & \\
\hline$\geq 14$ years & 1.23 & $(0.84-1.79)$ & & \\
\hline
\end{tabular}

* Variance Inflation Factor=1.120; †Adjusted binary logistic regression 1 : WAI+sex+age+function+length of time in function; $\neq$ Adjusted binary logistic regression 2: WAI+function+length of time in function; $\S p<0.0001$ 
The likelihood of the nursing workers who referred to MSP of strong or unbearable intensity being classified in the group with reduced work ability remain the same even after adjustments for potentially confounding factors (function and length of service in function).

\section{Discussion}

The high percentage $(91.4 \%)$ who referred to MSP ranging from weak to unbearable intensity in the seven days prior to the research denotes a serious health problem in the population studied and shows the importance of this problem among nursing workers. Research(2) investigating musculoskeletal symptoms in nursing workers concluded that the occurrence of musculoskeletal complaints in multiple regions of the body is high and that the factors were related to the moving and transporting of patients. Nursing work is often carried out in an uncomfortable and repetitive way, which may result equally in musculoskeletal pain and discomfort and in reduction in WAI.

When the WAI was evaluated, $41.4 \%$ of the nursing workers were classified as having a good work ability. These results corroborate other studies in which the percentages for good work ability varied from 41.8 to $80.0 \%{ }^{(8-9,16)}$. In spite of the high physical and mental demands resulting from the unhealthy hospital environment and in spite of the high percentage of workers with MSP, a larger number of workers have good work ability, which may indicate the existence of other factors, not measured in this study, which interfered positively in the WAI.

This study found a positive association both for MSP and for reduction in work ability among nursing workers. One study(17) evidenced a prevalence of inadequate work ability $84 \%$ higher in women compared to men $(P R=1.84$; CI 95\%=1.06-3.18).

Regarding the greater frequency of reports of MSP among female workers, the results are controversial ${ }^{18)}$. However, two possible reasons are presented(19) for this higher frequency: a) women experience more stress and use different coping strategies from men, resulting in a higher frequency of reports, and b) there may be differences in the processing of information about the somatic interpretation between men and women. There are authors ${ }^{(20)}$ who postulate that the fact that women tend to present higher rates of musculoskeletal injury makes them more likely to experience a reduction in WAI.

A statistically-significant association with reduction in work ability was evidenced $(p=0,021)$ in the evaluation of age range. This association was maintained in the model of logistical regression $(\mathrm{OR}=1.87$; CI95\% $=1.01$ - 3.46). Another study ${ }^{(9)}$ observed a reduced ability for work in workers with an average age of 44.2 years. Another(21) identified an inverse and weak correlation ( $r=-0.22 ; p=0.0394)$ between WAI and the worker's age, that is, the younger the nurse, the better the WAI scores. These results reinforce the need to be attentive to work ability and to work conditions, so as to keep the worker healthy throughout the years in which he or she shall remain in the workforce, avoiding premature aging and inability to work $^{(21)}$.

Among the work characteristics researched in this study, the following stand out as significant: the category of nurse technicians/auxiliary nurses, greater length of time in the function, and a weekly hour load of 30 hours per week. In relation to function, a significant association was indicated between being a nurse technician/ auxiliary nurse and a higher percentage of reference to musculoskeletal pain $(47.7 \% ; p=0.019)$ and a tendency to reduction of work ability ( $46 \% ; p=0.059)$. There is evidence, from previous studies ${ }^{(3-4)}$, that the category of auxiliary nurses has the highest frequency $(84.6 \%)$ of attendances in the occupational health department.

It may be that these results express the fact that the heaviest and most repetitive activities are carried out by this class of professionals. In the hierarchized and vertical division of nursing work, the hands-on tasks, most of the time, are carried out by the nurse technicians and auxiliary nurses, who have less autonomy of decision over their own work ${ }^{(18)}$. The intense rhythm, the repetitivity of the tasks and the time for accomplishing them in need to be added to this ${ }^{(22)}$. Such characteristics of nursing work, combined with the result found in this study that the workers with the greatest length of time in their function present the highest percentage of reports of MSP (49.8\%; $p=0.022)$ indicate the need for measures of intervention and health promotion as early as possible, starting from the professional's insertion into the work setting, so as to prevent or minimize work inability and the damage done to health ${ }^{(18)}$.

Regarding weekly hour load, the workers with 30 hours per week present a higher percentage for reduction of work ability $(p=0.026)$. In the institution researched, this workload corresponds to the workers who perform their activities in the night shift. Corroborating these findings, another study(11) also evidenced higher probabilities (OR 2.00; CI 1.01-3.95) of reduction in work ability. Despite the evaluation of shifts - in this study - not having found a significant difference between 
the groups ( $p>0.05)$, it is relevant to stress that night work alters the periods of sleep and causes the worker to exchange day for night, which break the human body's rules of physiological and chronobiological functioning. Many people also tend to alter their periods of sleep during the day, due to domestic tasks and noise, which reduce the time for relaxing and leisure ${ }^{(10)}$. In addition, night work causes chaos in the workers' daily rhythm, possibly causing malaise, fatigue, tiredness, insomnia, irritability, and impairment of mental quickness, performance and efficiency ${ }^{(23)}$; these physical and psychological impairments, added to the work overload, can potentialize poor work ability. However, as night work is indispensable for the continuity of nursing care, there is a need to seek individual and collective strategies to increase work ability. Among these: to alternate workers on the day and night shifts, to incentivize healthy habits and to invest in improving work conditions (good lighting, the implantation and incentivization of the practicing of workplace gymnastics) ${ }^{(24)}$.

An interesting aspect found in this study was that workers holding down two jobs have a more favorable WAI than those with only one job ( $p>0.05)$. This aspect deserves better elucidation, so as to investigate the mechanisms which may be contributing to these results. Preliminarily, one has to consider that aspects such as the need to add to one's income, the perspective of a better financial future, the pleasure gained from work, and the possibility of working with different people, managers and settings - which can lead the worker to re-think how to carry out his or her work, thus stopping routine activities from negatively affecting their health and work ability - may be mobilizing the majority of these workers for an WAI classified as good/excellent. Other research has evidenced a significant relationship between having two jobs and a reduced work ability ${ }^{(25)}$ and between not having another paid activity and excellent work ability ${ }^{(9)}$.

Regarding the confirmation of the present study's hypothesis, the result obtained may be added to others already published in this periodical, in the last two years, on the subject of evaluation of work ability(12-13) and contributes to the identification of a positive association between MSP of strong or unbearable intensity and reduced work ability. The need may therefore be seen for greater attention to these workers' health, and for keeping a watchful eye on work conditions, bearing in mind the need to reduce these professionals' pain and increase their work ability.
A study with nursing workers from the emergency sector ascertained that $28.6 \%$ of the workers with moderate, good or excellent WAI had a greater frequency of medical diagnosis of musculoskeletal illness ${ }^{(8)}$. These findings indicate that MSP is a reality present in the everyday, even for nursing workers classified as having good work ability. This fact justifies the importance of adopting preventive and interventional measures, both on the part of workers and on the part of managers.

Among this study's limitations, it stands out that as a cross-sectional study, it is not possible to form conclusions, with certainty, in regard to causal relationships, considering that these studies investigate simultaneously the exposure and the condition of the subject's health. In addition, it stands out that workers on leave for health treatment reasons were not included, which may influence the results through the bias of the effect of the healthy worker.

\section{Conclusions}

It is concluded that the largest percentage of the nursing workers $(91.4 \%)$ mentioned pain with weak to unbearable intensity, and that $43.3 \%$ had reduced work ability. In the context of illness among nursing workers, MSP of the conditions that affects these workers most, and which contributes to reducing work ability - a fact confirmed by this study. It was also identified that the likelihood of nursing workers who mentioned MSP of strong to unbearable intensity being classified in the group with reduced work ability remained.

Thus, the evaluation of WAI becomes relevant, considering that it provides support for the implementation of measures for health promotion and the prevention of harm, so as to function in the work environment where the worker is inserted. With this, based on this study's results, it is sought to offer support to establish actions which preserve professionals' work ability in this and other institutions. One strategy to minimize this problem would be to adopt participative management, in the sense of getting the workers involved in discussions and raising shortcomings in the process and organization of work, so as to find the best solutions for the problems and to safeguard their right to health at work. The adoption of longitudinal studies is suggested, so as to ascertain the cause and effect between exposure and outcome, as well as the measuring of other variables which could interfere in work ability. 


\section{References}

1. Ministério da Saúde (BR). Instrução normativa INSS/ DC n 98, de 05 de dezembro de 2003. Aprova Norma Técnica sobre Lesões por Esforços Repetitivos - LER ou Distúrbios Osteomusculares Relacionados ao TrabalhoDORT. Brasília (DF): Ministério da Saúde; 2003.

2. Gurgueira GP, Alexandre NMC, Corrêa Filho HR. Prevalência de sintomas músculo-esqueléticos em trabalhadoras de enfermagem. Rev. Latino-Am. Enfermagem. 2003;11(5):608-13.

3. Varela $C D$, Ferreira SL. Perfil das trabalhadoras de enfermagem com diagnóstico de LER/DORT em SalvadorBahia 1998-2002. Rev Bras Enferm. 2004;57(3):321-5. 4. Murofuse NT, Marziale MHP. Doenças do sistema osteomuscular em trabalhadores de enfermagem. Rev. Latino-Am. Enfermagem. 2005;13(3):264-73.

5. Magnago TSBS, Lisboa MTL, Griep RH, Kirchhof ALC, Guido LA. Psychosocial aspects of work and musculoskeletal disorders in nursing workers. Rev. Latino-Am. Enfermagem. 2010;18(3):429-35.

6. Fonseca NR, Fernandes RCP. Factors Related to Musculoskeletal Disorders in Nursing Workers. Rev. Latino-Am. Enfermagem. 2010;18(6):1076-83.

7. Karasek $\mathrm{R}$, Theörell $\mathrm{T}$. Healthy work-stress, productivity, and the reconstruction of working life. New York: Basic Books; 1990.

8. Duran ECM, Cocco MIM. Capacidade para o trabalho entre trabalhadores de enfermagem do prontosocorro de um hospital universitário. Rev. Latino-Am. Enfermagem. 2004;12(1):43-9.

9. Raffone AM, Hennington E.A. Avaliação da capacidade funcional dos trabalhadores de enfermagem. Rev Saúde Pública. 2005;39(4):669-76.

10. Fischer FM, Borges NS, Rotenberg L, Latorre MRDO, Soares NS, Rosa PLFS et al. A (in)capacidade para o trabalho em trabalhadores de Enfermagem. Rev Bras Med Trab. 2005;3(2):97-103.

11. Rotenberg L; Griep RH; Fischer FM; Fonseca Mde J; Landsbergis P. Working at night and work ability among nursing personnel: when precarious employment makes the difference. Int Arch Occup Environ Health. 2009;82(7):877-85.

12. Hilleshein EF, Lautert L. Work capacity, sociodemographic and work characteristics of nurses at a university hospital. Rev. Latino-Am. Enfermagem. 2012;20(3):520-7.

13. Negeliskii C, Lautert L. Occupational stress and work capacity of nurses of a hospital group. Rev Latino-Am. Enfermagem. 2011;19(3):603-13.
14. Tuomi K, Ilmarinen J, Jahkola A, Katajarinne L, Tulkki A. Índice de Capacidade para o Trabalho. Tradução de FM Fischer. Helsinki: Instituto de Saúde Ocupacional; 2005. 15. Jensen MP, Karoly $P$, Braver $S$. The measurement of clinical pain intensity: a comparison of six methods. Pain. 1986;27(1):117-26.

16. Martinez MC, Latorre MRDO, Fischer FM. Work ability: a literature review. Ciênc Saúde Coletiva. 2010;15(Supl.1):1553-61.

17. Vasconcelos SP, Fischer FM, Reis AOA, Moreno CRC. Fatores associados à capacidade para o trabalho e percepção de fadiga em trabalhadores de enfermagem da Amazônia Ocidental. Rev Bras Epidemiol. 2011;14(4):688-97

18. Magnago TSBS, Lisboa MTL, Griep RH, Kirchhof ALC, Camponogara S, Nonnenmacher CQ, et al. Nursing workers: work conditions, social-demographic characteristics and skeletal muscle disturbances. Acta Paul Enferm. 2010;23(2):187-93.

19. Willians PG, Wiebe DJ. Individual differences in self-assessed health: gender, neuroticism and physical symptom reports. Pers Individ Dif. 2002;28(5):823-35. 20. Walsh IAP, Corral S, Franco RN, Canetti EEF, Alem MER, Coury HJCG. Capacidade para o trabalho em indivíduos com lesões músculo-esqueléticas crônicas. Rev Saúde Pública. 2004;38(2):149-56.

21. Hilleshein EF, Souza LM, Lautert Liana, Paz AA, Catalan VM, Teixeira MG, Mello DB. Capacidade para o trabalho de enfermeiros de um hospital universitário. Rev Gaúcha Enferm. 2011;32(3):509-15.

22. Mello MC, Fugulin FMT, Gaidzinski RR. O tempo no processo de trabalho em saúde: uma abordagem sociológica. Acta Paul Enferm. 2007;20(1):87-90.

23. Campos MLP, Martino MMF. Aspectos cronobiológicos do ciclo vigília-sono e níveis de ansiedade dos enfermeiros nos diferentes turnos de trabalho. Rev Esc Enferm USP. 2004;38(4):415-21.

24. Silva RM, Beck CLC, Magnago TSBS, Carmagnani MIS, Tavares JP, Prestes FC. Trabalho noturno e a repercussão na saúde dos enfermeiros. Esc Anna Nery. 2011;15(2):270-6.

25. Monteiro MI, Fernandes ACP. Capacidade para o trabalho de trabalhadores de empresa de tecnologia da informação. Rev Bras Enferm. 2006;59(5):603-8. 